\title{
Impacts of the spirit of initiative and identification with the organization on IT governance effectiveness perception in public organizations
}

Guilherme Costa Wiedenhöft

Escola Politécnica, Pontificia Universidade Catolica do Rio Grande do Sul, Porto Alegre, Brazil

Edimara Mezzomo Luciano

Programa de Pós-Graduação em Administração, Pontificia Universidade Catolica do Rio Grande do Sul, Porto Alegre, Brazil, and

Josiane Brietzke Porto

Escola Politécnica, Universidade do Vale do Rio dos Sinos, Sao Leopoldo, Brazil

\begin{abstract}
Purpose - The purpose of this paper is to address the process of organizational governance of IT resources, called IT governance (ITG), especially its behavioral approach. The organizational citizenship behavior (OCB) concept was used to understand the relationship between the behavioral dimensions and the perception of ITG effectiveness. The objective of this research is to identify if individuals' behavior contributes to a greater perception of ITG effectiveness in public organizations. This is an exploratory and descriptive research with a quantitative approach.

Design/methodology/approach - This was an exploratory and descriptive research with a quantitative approach. A survey with IT teams of public organizations in a Brazilian state was performed, and data were analyzed through partial least squares. A positive and significant relationship between the variables Spirit of Initiative $\left(R^{2}=0.2926\right)$ and Identification with the Organization $\left(R^{2}=0.1276\right)$, and the perception of ITG effectiveness was found.

Findings - Results showed that when OCB levels are higher, ITG is more easily perceived as effective. This occurs because the predisposition to adopt ITG mechanisms increases the changes in the governance process, which are understood as significant by the organization. In addition, it is important to consider the impact of change on individuals, due to ITG adoption. This reinforces that ITG is not just about the IT department, but also refers to its adoption and use throughout the organization as a key resource for the implementation of public policies and for following governmental strategies.

Research limitations/implications - The predictive capacity of the proposed relationship model requires a larger number of confirmatory studies. Its application is suggested in other federative units or in private organizations.

Practical implications - OCB increases the predisposition to adopt ITG mechanisms, provided they understand that changes in the governance process are important to the organization. The change impact on individuals due to ITG adoption is also relevant, which shows that ITG is not only about the IT department, but also about IT adoption and its use throughout the organization.
\end{abstract}

(C) Guilherme Costa Wiedenhöft, Edimara Mezzomo Luciano and Josiane Brietzke Porto. Published in Revista de Gestão. Published by Emerald Publishing Limited. This article is published under the Creative Commons Attribution (CC BY 4.0) licence. Anyone may reproduce, distribute, translate and create derivative works of this article (for both commercial and non-commercial purposes), subject to full attribution to the original publication and authors. The full terms of this licence may be seen at http://creativecommons.org/licences/by/4.0/legalcode
ITG effectiveness perception

Received 9 January 2018 Revised 17 August 2018 18 September 2018 Accepted 20 September 2018

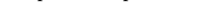


REGE

26,1

Originality/value - The paper helps understanding the behavioral effects on the effectiveness of the GTI, since the simple adoption of GTI mechanisms does not guarantee that they are effective in achieving its objective of responding to governmental demands.

Keywords Organizational citizenship behaviour (OCB), Organizational behaviour, IT governance, Effectiveness, Public organizations, Partial least squares

Paper type Research paper

\section{Introduction}

Connections between government and citizens are changing (Cunha and Miranda, 2013), and this process creates new demands for fast and reliable data, information and services whose implementation depends on, involves or is enabled by IT solutions (Luciano et al., 2016). These initiatives are implemented through a complex network of public and private actors (who work in commissioned public services), which aim to improve public services to citizens, increase effectiveness and extend transparency in public management. Considering that these goals are very distinct and complex, although complementary, it is important to establish a governance structure to orchestrate all actors and efforts, which contributes to reduce risks in service delivery. Decision making on ICT outside a governance process can more easily increase ad hoc solutions (Nfuka and Rusu, 2011), which, in turn, unnecessarily raise complexity and transaction costs, undermining future investments and hampering the planning of new initiatives, as well as the management of current ones. Gradually, key IT issues are no longer about the organization's software and hardware but have moved to the strategic level, dealing with definitions and policies on how technology and its resources should be used to create a competitive advantage for organizations (Bartenschlager and Goeken, 2010), or public value, in the case of public organizations. This shows that IT governance (ITG) does not address the IT department, but it is about IT adoption and its use throughout the organization.

Governance in public organizations involves processes and structures for decision making on public policies and their management, to engage people from different government levels and other public and private agents in order to achieve a public purpose that, otherwise, could not be attained (Peters, 1998). It also concerns the decision on how much coordination and control are appropriate in each situation and context (Grandori, 1997). When applied to IT decisions, governance can be understood as a set of authority arrangements and standards for IT strategic activities (Sambamurthy and Zmud, 1999), composed of a group of structure, process and relationship mechanisms that implement high-level definitions. A governance process applied to IT regards the decision-making framework and the establishment of rights and responsibilities to encourage desirable behaviors related to IT (Weill and Ross, 2004).

ITG studies suggest the existence of two main paths of action for adopting its mechanisms (Sambamurthy and Zmud, 1999; Peterson, 2004; Van Grembergen et al., 2004; Weill and Ross, 2004; Huang et al., 2010). One of the pillars focuses on legal and regulatory aspects and the other one focuses on the behavioral factor inherent to individuals that deal with IT, in its different expressions - IT artifacts (equipment, tools and applications), information and usage policies. ITG mechanisms should be able to encourage the desired behavior of individuals regarding IT aspects (Weill and Ross, 2004). The incentive for the desirable behavior complements the normative side of governance, contributing to a consistent and aligned relationship between business and IT. This behavioral expression of ITG is the focus of this research.

In public organizations, the adoption of normative and control mechanisms is not sufficient to achieve ITG effectiveness, since they cannot handle all situations related to the use of IT resources in such organizations; thus, each individual should interpret the situation and position himself/herself in order to contribute the most to attain the organization's goals. Therefore, non-prescribed behaviors (in laws, decrees, ordinances and policies) are necessary 
to solve the individual's predicament in the organization, created by non-standard and non-regulated situations. A non-regulated situation that can paralize the activities demands an extra-role behavior.

Organizational citizenship behavior (OCB) describes the voluntary commitment of a person to an organization, with attitudes that are not part of his/her contractual functions (Rego et al., 2010). It consists of protection actions taken by the employees, which aim to safeguard an organization and everything that belongs to it, contributing to a favorable environment. For example, even if the norm for a particular acquisition is a monocratic and individual decision, a civil servant with a high OCB can suggest that a collegiate decision would be more appropriate for the situation, due to its potential implications, thus protecting the institution from future issues.

The objective of this study was to identify the dimensions of OCB that contribute to increase the effectiveness of ITG through the perception of IT individuals who work in public organizations. It is important to understand the behavioral effects on ITG perceived effectiveness, since the simple adoption of ITG mechanisms does not ensure that they will be effective in meeting governmental demands. This situation happens because the adoption of such mechanisms can be done through phenomena such as mimetic, normative and coercive isomorphism, hindering the alignment with public organizations' objectives or being considered illegitimate by their employees.

In addition to this Introduction, the paper has four more sections. The theoretical framework that supports the research is presented in Section 2. Section 3 presents the methodological procedures adopted, followed by the results and main findings (Section 4). Section 5 discusses the final remarks and suggestions for future research.

\section{Theoretical framework}

This section addresses the conceptual aspects that are part of this study, such as ITG and OCB.

\subsection{Governance of IT resources in public organizations}

Public management reform has three ways to ensure transparency: social control; control through management contracts and results; and controlled competition. The principles that guided public management reform were oriented to results, efficiency, governance and market practices (Diniz et al., 2009). Accordingly, the complexity of government's modern problems requires more efficient managers, and also the need to consider the relevance of organizations' behavioral and cultural aspects, which are key factors for solving these problems (Bresser-Pereira, 2002).

IT use enabled the change in the public management model, with the emergence of electronic government (e-Gov) and citizen-oriented services (Diniz et al., 2009). IT can be a solution for governments, with regard to the growing demand for transparency and accountability (Joia, 2009). The internet arrival has brought greater visibility to public organizations by disseminating their e-Gov applications worldwide, which led to the increase in the number of organizations that use ICTs (Heeks, 2005).

In Brazil, several authors have focused on the topic of IT use in public organizations, such as Cunha et al. (2009), Diniz et al. (2009), Medeiros and Guimarães (2006), Joia (2009) and Laia et al. (2011). They mainly address e-government and IT use in public services, IT use for governance and democracy, and the strategic use of technology in governments, which involves government services and sociocultural impacts of ICT.

Barrett (2001) highlights the differences between public and private organizations, regarding ITG. In the former, there is a greater influence of the political environment and value systems, which emphasize compliance with legal provisions. ITG models in the public and private sectors are similar in their basic pillars (principles, objectives and mechanisms), 
REGE 26,1

but the sectors are very different in terms of environmental aspects that involve external and internal institutional pressures. Moreover, institutional pressures are an important source of demands for IT areas in public organizations, and the financial and market pressures, inherent to the private sector, are driving forces of demand in companies (Rodrigues and Souza, 2012). For the authors, the biggest divergence between public and private sectors is how agents responsible for governance react to these pressures.

ITG in public organizations can be understood as the financial and administrative capacity to implement public policies that aim to make the State stronger, by overcoming the fiscal crisis, delimiting its area of activity, distinguishing between the strategic core and decentralized units, establishing a political elite able to make the necessary decisions and allocating a motivated and skilled bureaucracy (Cunha, 2000). Diniz et al. (2009) provide a broad view of electronic governance that considers the internal elements of public administration, such as processes, relationships and structures, and external aspects such as public services, participation and control.

According to Rocheleau and $\mathrm{Wu}$ (2002), the main difference between ITG in the public and private sectors lies in the fact that the public sector provides public goods and services, rather than services or products for sale. However, ITG in the public sector does not show significant conceptual differences from ITG in the private sector. Therefore, the IT complex environment and IGT weaknesses in the Brazilian public sector are mainly caused by the absence of a good public governance, due to institutional and behavioral aspects.

ITG can be understood through the synergy of mechanisms arranged in three main pillars: structure, processes and relationships. Structural arrangements are formed by business units and their roles and responsibilities, for the correct decision making on IT (Weill and Ross, 2004). Process arrangements and practices are directed toward the implementation of management and definition of procedures according to the strategies and policies defined for IT. The relationship ensures that defined arrangements and ITG processes are conducted to guarantee the effectiveness of use of IT assets, enabling them to seize opportunities and add higher value to the business (Bowen et al., 2007).

In recent years, different authors tried to identify the main ITG mechanisms, such as Sambamurthy and Zmud (1999) and Peterson (2004), who distinguished the process, relationship and structure mechanisms. Van Grembergen et al. (2004) studied the mechanisms in the European context based on market frameworks, while Weill and Ross (2004) and Huang et al. (2010) addressed the deliberative committees and the importance of roles and responsibilities. In Brazil, Lunardi et al. (2010) and Wiedenhoft and Klein (2013) gave attention to specific mechanisms for local companies. However, Peterson (2004) was one of the first scholars to define a set of mechanisms for ITG, arguing that they act in order to meet the organization's goals regarding IT, by respecting the principles of corporate or organizational governance. As a result, these mechanisms must be associated with one or more ITG objectives (Van Grembergen et al., 2004).

In the perception of Weill and Ross (2004), the structure, processes and relationship mechanisms are the main way to express IGT needs. These mechanisms take into account the organizational arrangements for IT decision making, the processes that make IT work and the relationships to address and manage the different activities involved.

The relevance of the studies on ITG mechanisms is evident in the international academic scene, as several researchers have addressed these arrangements and practices, in recent years. Bowen et al. (2007) conducted a case study in a large organization, exploring the elements that affect ITG mechanisms, and showed that ITG performance is associated with mechanisms such as the shared understanding of business and IT objectives, the active involvement of IT committees in direction and decisions, and strategies and policies shared and communicated between business and IT. Weill and Ross (2004), through a survey of 250 companies from different countries, demonstrated 
that the adoption of ITG mechanisms can be a profitable investment, especially those of decision making and relationship.

Ali and Green (2007) suggest a positive and significant correlation between the general level of ITG effectiveness and the relationship mechanisms, mainly those involving top management in IT, ethics or culture of compliance with policies, guidelines and procedures, and the set of formal/informal communication practices. Prasad et al. (2010) suggest that organizations that have ITG framework mechanisms, such as IT strategy committees and IT steering committee, show high levels of performance and a greater capacity of IT resources. Wu et al. (2015) examined the relationship between ITG and the mechanisms of IT strategic planning/information systems, performance measurement systems and methods for assessing the levels of IT strategic alignment and organizational performance. Results show that strategic alignment is an important factor for enhancing ITG effect on company's effectiveness.

Regardless of the strategic positioning of organizations, the adoption of ITG mechanisms has become an essential discussion in the agenda. In this sense, organizations try to increase assertiveness in relation to the adoption of ITG mechanisms, so that they help to achieve top management's expected goals (Weill and Ross, 2004). The decision or choice of which ITG mechanisms to adopt in organizations should be based on the effectiveness model implemented by them, in line with what they showed. However, decisions in organizations are often made on the basis of subjective stimuli, in an unconscious quest for legitimation.

\subsection{Organizational citizenship behavior $(O C B)$}

Organizations face a dilemma. While it is essential that employees carry out what they have been assigned for by contract, they require that individuals choose behaviors that go beyond the demands of their role (Cunha et al., 2006). The importance of this type of behavior for organizations stems from their need of flexibility to deal with many unexpected situations that arise in the organizational daily routine (Smith et al., 1983). Based on these authors and a series of previous studies, the term OCB was academically established.

OCB dimensions include behaviors related to the individual's attitudes toward the organization, expressed through the dimensions conscientiousness, sportsmanship and civic virtue, which refer to situations in which an individual complies with the rules and regulations even when no one sees it, or when he/she adopts an attitude that benefits the organization's image (Rego, 1999). In its dimensions of altruism and courtesy, OCB expresses the individual behaviors in relation to other members of the organization, showing an individual and/or organizational focus. It is important to acknowledge that cultural contexts may interfere with conceptions of what can or cannot be understood as OCB (Rego, 2002). Some OCB dimensions may be specific to the country/culture where studies are carried out, and cannot be considered universal for all contexts.

Cultural contexts are elements that contribute to the contingency view of OCB dimensions (Paine and Organ, 2000; Paillé et al., 2010). Rego (1999), based on the assumption that OCB has a contingency attribute, validated an instrument adapted to the Portuguese reality, in which four OCB dimensions emerged, as shown in Table I.

Different modus operandi affect the need for extra-role behaviors. In countries with clearer and more stable rules and regulations, it is less necessary to adopt an extra-role behavior, since the chances of having clear laws, rules, policies, manuals and processes are bigger than in countries with cultures that do not appreciate law enforcement. It is important to understand that OCB is not an inappropriate or improper behavior, but rather a necessary one for developing activities. As an example, in a situation where rules, processes or policies refer to each other, creating a loop, the employee must adopt an extra-role behavior and decide how to solve the issue, so that the process goes forward and 
REGE

26,1

10

OCB dimensions

\section{OCB dimension}

Interpersonal Harmony (IH)

Conscientiousness (CO)

Spirit of Initiative (SI)

Identification with the

Organization (IO)
Description

Dimension related to interpersonal harmony, participation, team spirit, companionship and share of knowledge and experience

Dimension that reflects behaviors of obedience, conscientiousness and protection of the organization's resources

Dimension that reveals spirit of initiative, availability to solve problems and find alternative solutions, spontaneity in making constructive suggestions for improvement

Dimension that shows that the individual makes extra efforts and tries to defend the organization's image with attitudes that praise its positive aspects in front of people outside the organization

Source: Adapted from Rego (1999)

the organization provides its services. Of course, there are extra-role behaviors that may have other intentions, not linked to the organization's preservation, but these are not the OCB focus.

\section{Research method}

This is an exploratory and cross-sectional descriptive research, with a quantitative focus, given the techniques used for data collection and analysis. A survey was conducted considering it was the appropriate approach for the research purpose and strategy. Figure 1 presents the main stages of the research protocol.

After identifying the concepts and approaches related to the research topic, we created and validated a research instrument by using the statistical tests described in the following sections. After validation, we collected and analyzed data statistically, in order to attain the research objective.

\subsection{Development and validation of the research instrument}

In order to study the relationships between the variables OCB and ITG perceived effectiveness, we developed the structural model, shown in Figure 2, which served as a basis for building the data collection instrument (questionnaire).

The model presents the variables and relationships analyzed in our study, which show the influence of OCB dimensions on the perception of ITG effectiveness. We divided the instrument in three parts, with six questions, in a six-point six-point Likert type scale, to evaluate ITG Perceived Effectiveness (based on Luciano et al., 2016); 15 questions, in a six-point agreement scale of the Likert type, to assess OCB

Figure 1.

Research design

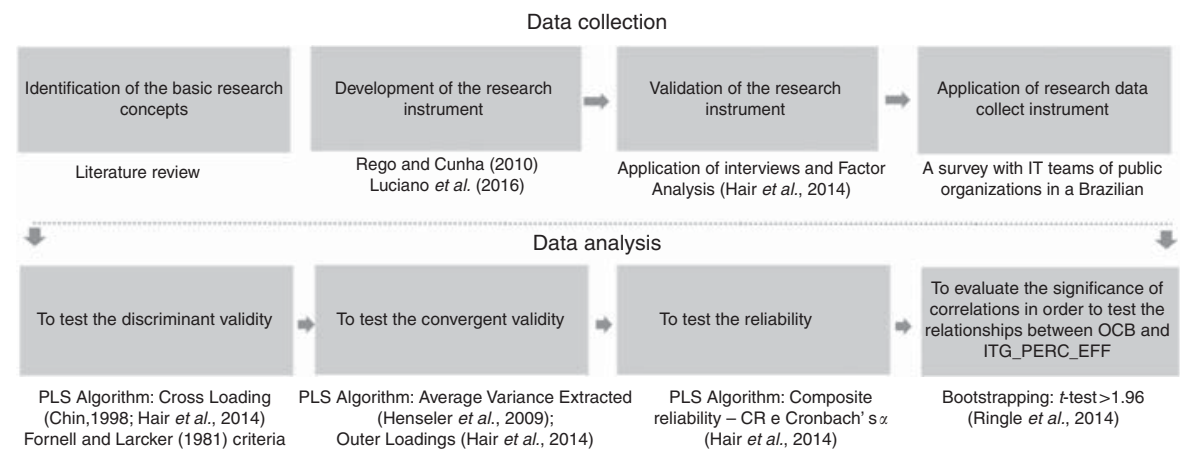




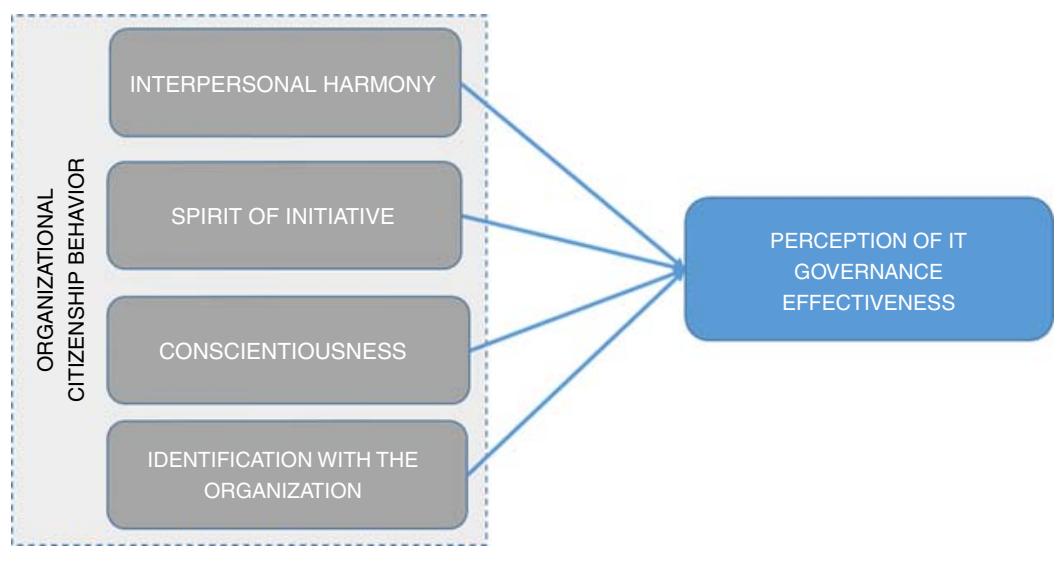

ITG effectiveness perception

(adapted from Rego, 1999, 2002); and 9 open questions for the socio-demographic characterization, as shown in Table II.

We defined the respondents' profile as civil servants working directly in the IT area or in related areas, representing the business in IT matters, with a minimum of two years of working at the institution - we assumed that these employees would be more familiar with ITG mechanisms. We submitted the first version of the instrument to four researchers who study ITG or have a focus on public administration, in order to receive suggestions to better adapt it to the objectives and to the respondents' profile. We carried out the instrument's face validation through a group discussion with 11 civil servants that are members of one of the ITG committees in the state of Rio Grande do Sul (RS). Thereafter, the suggestions considered relevant led to some changes, mainly by adjusting the instrument's language to the respondents.

Finally, we conducted a survey with IT civil servants of Thereafter RS Government, in order to collect the necessary data for the instrument's pre-test. Due to the complexity of their profile and the difficulty to access them, we chose to collect data and perform post hoc tests by using the free software G*Power 3.1.9 (Faul et al., 2009). The sample's power test, for the 74 valid cases, resulted in a Power $(1-\beta$ err prob) value equal to 0.7336 , with the effect size $\left(f^{2}\right)$ of 0.15 . Hair et al. (2014) recommend Power values close to 0.80 , with effect size $\left(f^{2}\right)$ of 0.15 . There was a small difference between the recommended and achieved values; however, we understood that the sample was appropriate because these were pretest data that could be corrected during the final data collection.

In order to ensure data suitability, due to the complexity of respondents' profile, we analyzed the correlation matrix, where the value of 0.781 of the Kaiser-Meyer-Olkin test, as well as Bartlett's sphericity test $\left(\chi^{2}=1,797.802 ; \mathrm{df}=465\right.$ and $\left.p=0.000\right)$ showed that the data were appropriate for factor analysis. Thus, we proceeded with the analysis of the main components, through which we could demonstrate that the five factors correspond to 71.54 percent of the total variance explained. Finally, to test the reliability of the research instrument, we carried out Cronbach's $\alpha$ test (0.862), based on standardized items (0.850), for the 21 items of the questionnaire, which demonstrated the applicability of the instrument for the final data collection.

\subsection{Data collection}

We carried out the final data collection during the second semester of 2016, in government bodies and sectors of the Direct Administration of the state of Rio Grande do Sul, which has around 1,200 employees working in IT areas. A total of 500 printed questionnaires 
REGE

26,1

12

Table II.

Constructs, variables and factors

Construct Variable Factors

Organizational

Conscientiousness They are sloppy (they do not care if the work is well or poorly done) citizenship behavior (CO)

(OCB)

Spirit of Initiative

(SI)

They are mentally fresh and ready to work as soon as they arrive at the organization

They waste time with issues unrelated to the task

They keep informed about what happens in the organization

When there are problems, they try to solve them before

presenting them to their superiors

When something does not work, they look for alternatives to make it work

They spontaneously try to improve their knowledge, competences and skills

Interpersonal They are always complaining about trivial matters

Harmony (IH) (of low importance)

They create instability in the team (through gossips and intrigues) When they have unpleasant or difficult tasks to do, they try to "pass the buck" to others

They always refer to the negative side of things, more than to the positive side

When something negative happens to them, they apologize for others' mistakes

Organizational They make extra efforts to benefit the organization, even with Identity (OI) personal damages

In the first place, they think about the activities, more than in themselves

When they find out a business opportunity for the organization (even on weekends), they inform the responsible persons

Effectiveness of IT ITG Perceived governance Effectiveness IT governance mechanisms provide ICT services with focus on the customer

mechanisms (EFF) (ITG_PERC_EFF)

systems and processes

IT governance mechanisms promote networks of collaboration and diffusion of ICT knowledge

Governance mechanisms ensure the optimization of ICT resources ICT governance mechanisms focus on customers' needs Governance mechanisms promote the integration between different bodies of the State Government

were distributed and collected in person. The answers were then tabulated using Qualtrics ${ }^{\circledR}$ software. As suggested by Hair et al. (2014), data purification was done by removing the cases that had incomplete answers (at least one blank question in blocks 1 or 2), duplicate answers or levels of standardized responses equal or higher than 75 percent (items marked in the same item of the scale). At the end, 243 valid cases remained. Valid responses for the final analysis represent a heterogeneous stratum of RS bodies of direct administration, as shown in Table III.

Finally, the Kolmogorov-Smirnov test conducted with valid data could not determine the sample normality, as presented in Table IV.

Therefore, we chose to use structural equations modeling with partial least squares (SEM-PLS) (Hair et al., 2014; Koufteros, 1999).

\subsection{Data analysis}

We used the partial least squares (PLS) method for data analysis. According to Hair et al. (2014), PLS was developed to maximize the predictive accuracy of models, offering flexibility 


\begin{tabular}{|c|c|c|c|c|}
\hline $\begin{array}{l}\text { Position } \\
\text { (no. of observations) }\end{array}$ & $\begin{array}{l}\text { Gender } \\
\text { (no. of observations) }\end{array}$ & $\begin{array}{l}\text { Qualification } \\
\text { (no. of observations) }\end{array}$ & $\begin{array}{l}\text { Time in organization/sector } \\
\text { (average in years) }\end{array}$ & effectiveness \\
\hline Technician or Assistant (99) & $\begin{array}{l}\text { Male (69) } \\
\text { Female (30) }\end{array}$ & $\begin{array}{l}\text { Graduate (55) } \\
\text { Specialist (33) } \\
\text { Ongoing Master (5) } \\
\text { Concluded Master (5) } \\
\text { Concluded PhD (1) }\end{array}$ & 12.53 & 13 \\
\hline Analyst (83) & $\begin{array}{l}\text { Male (61) } \\
\text { Female (22) }\end{array}$ & $\begin{array}{l}\text { Graduate (37) } \\
\text { Specialist (38) } \\
\text { Concluded Master (6) } \\
\text { Ongoing PhD (2) }\end{array}$ & 11.91 & \\
\hline Coordinator (22) & $\begin{array}{l}\text { Male (18) } \\
\text { Female (4) }\end{array}$ & $\begin{array}{l}\text { Graduate (7) } \\
\text { Specialist (9) } \\
\text { Ongoing Master (5) } \\
\text { Concluded Master (1) }\end{array}$ & 10.32 & \\
\hline Specialist (5) & $\begin{array}{l}\text { Male (4) } \\
\text { Female (1) }\end{array}$ & $\begin{array}{l}\text { Graduate (2) } \\
\text { Specialist (2) } \\
\text { Concluded Master (1) }\end{array}$ & 14.60 & \\
\hline Manager (27) & $\begin{array}{l}\text { Male (22) } \\
\text { Female (5) }\end{array}$ & $\begin{array}{l}\text { Graduate (9) } \\
\text { Specialist (17) } \\
\text { Ongoing Master (1) }\end{array}$ & 11.00 & \\
\hline Director (7) & Male (7) & $\begin{array}{l}\text { Graduate (5) } \\
\text { Specialist (1) } \\
\text { Concluded Master (1) }\end{array}$ & 5.71 & \\
\hline Total (243) & $\begin{array}{l}\text { Male (181) } \\
\text { Female (62) }\end{array}$ & $\begin{array}{l}\text { Graduate (115) } \\
\text { Specialist (100) } \\
\text { Ongoing Master (11) } \\
\text { Concluded Master (14) } \\
\text { Ongoing PhD (2) } \\
\text { Concluded PhD (1) }\end{array}$ & 11.81 & $\begin{array}{l}\text { Table III. } \\
\text { Characterization of } \\
\text { respondents }\end{array}$ \\
\hline
\end{tabular}

\begin{tabular}{|c|c|c|c|c|}
\hline \multirow[b]{2}{*}{ Variables } & \multicolumn{3}{|c|}{ Kolmogorov-Smirnov (Lilliefors significance correction) } & \\
\hline & Statistics & $\mathrm{df}$ & Sig. & \\
\hline OCB_CO1 & 0.215 & 243 & 0.000 & \\
\hline OCB_CO2 & 0.177 & 243 & 0.000 & \\
\hline OCB_CO3 & 0.152 & 243 & 0.000 & \\
\hline OCB_SI1 & 0.203 & 243 & 0.000 & \\
\hline OCB_SI2 & 0.248 & 243 & 0.000 & \\
\hline OCB_SI3 & 0.276 & 243 & 0.000 & \\
\hline OCB_SI4 & 0.225 & 243 & 0.000 & \\
\hline OCB_IH1 & 0.150 & 243 & 0.000 & \\
\hline OCB_IH2 & 0.165 & 243 & 0.000 & \\
\hline OCB_IH3 & 0.140 & 243 & 0.000 & \\
\hline OCB_IH4 & 0.157 & 243 & 0.000 & \\
\hline OCB_IH5 & 0.145 & 243 & 0.000 & \\
\hline OCB_OI1 & 0.184 & 243 & 0.000 & \\
\hline OCB_OI2 & 0.173 & 243 & 0.000 & \\
\hline OCB_OI3 & 0.178 & 243 & 0.000 & \\
\hline EFF_OB1 & 0.230 & 243 & 0.000 & \\
\hline EFF_OB2 & 0.194 & 243 & 0.000 & \\
\hline EFF_PR1 & 0.169 & 243 & 0.000 & \\
\hline EFF_PR2 & 0.188 & 243 & 0.000 & Table IV. \\
\hline EFF_PR3 & 0.232 & 243 & 0.000 & Kolmogorov-Smirnov \\
\hline EFF_PR4 & 0.183 & 243 & 0.000 & normality test \\
\hline
\end{tabular}


REGE

26,1

for structural equations modeling, since there are no assumptions on variables distribution; thus, there is no need to change the indicators in order to reduce their asymmetry. In addition, the necessary sample size is smaller than in SEM, based on covariance. Analysis in this research stage was carried out through the tool SmartPLS ${ }^{\circledR}$ version 2. To test the relationship between the behavioral dimensions of Organizational Citizenship and ITG Perceived Effectiveness, data were inserted into SmartPLS ${ }^{\circledR}$. Then, we designed the first-order model, where each of the four variables of the OCB construct was linked to the ITG Perceived Effectiveness construct, as observed in Figure 3.

The analysis of the measurement model began with the assessment of the discriminant validity, achieved as latent constructs or variables showed to be independent of each other (Hair et al., 2014). We verified cross-loadings between the observable variables and their factors, as recommended by Ringle et al. (2014). Table V presents the discriminant validity test, based on cross-loadings analysis (Chin, 1998). Indicators must have higher factor loads in their respective latent variables (or constructs) than in others (Chin, 1998). The second aspect is Fornell and Larcker's (1981) criterion, in which the square roots of the average variance extracted (AVE) of each latent variable (or construct) are compared with Pearson's correlations between the constructs. AVE's square roots should be higher than the correlations between the constructs.

It was possible to determine that the model has discriminant validity, by the results of the cross-loadings analyses, according to the parameters defined by Chin (1998). Results obtained in the convergent validity and reliability test are presented in Table VI. The first item to be observed in the analysis of the structural model refers to the values of Pearson determination coefficients $\left(R^{2}\right) . R^{2}$ indicators evaluate the portion of the variance of the endogenous variables that is explained by the structural model, thus indicating the quality of the adjusted model (Ringle et al., 2014).

Table VII presents the values of the Pearson determination coefficients $\left(R^{2}\right)$. All tests carried out herein allow us to conclude that the proposed model is suitable for identifying which dimensions of OCB contribute to increase the effectiveness of ITG, in the perception of individuals that work with IT in public organizations. Thus, we calculated the $t$-values between data original values and those obtained by the resampling technique, by using the SmartPLS ${ }^{\circledR}$ Bootstrapping module, a nonparametric procedure in which sub-samples are

Figure 3.

Relationship between OCB dimensions and ITG perceived effectiveness

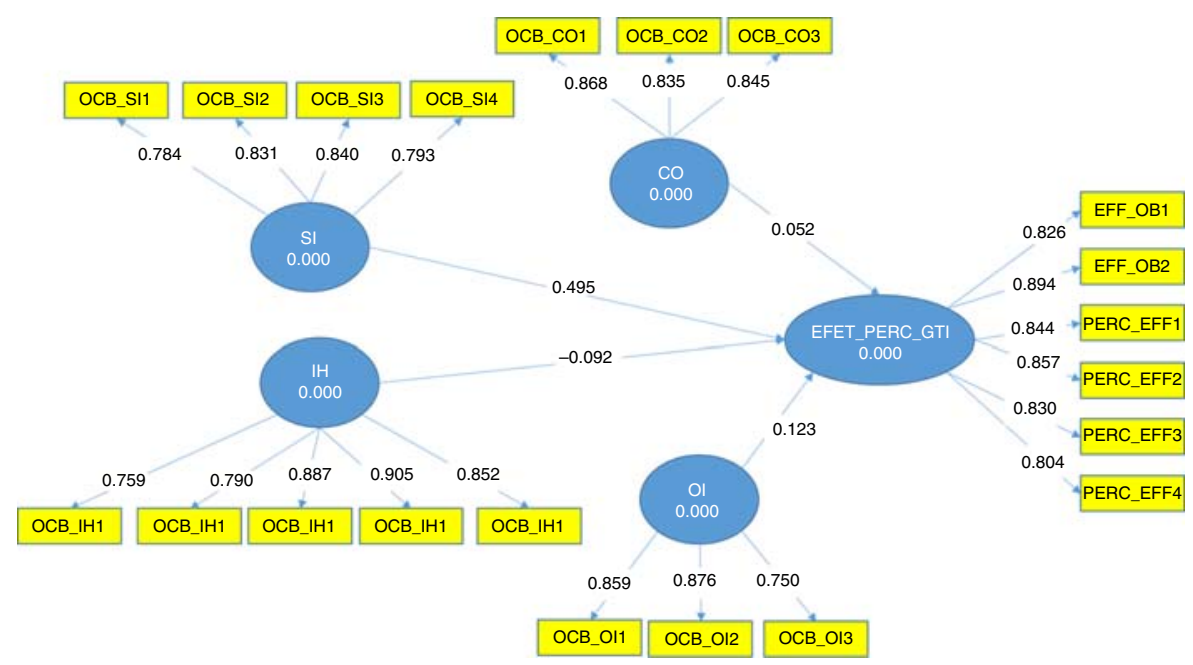




\begin{tabular}{|c|c|c|c|c|c|c|}
\hline Variables & $\mathrm{CO}$ & SI & $\mathrm{IH}$ & OI & ITG_PERC_EFF & ITG \\
\hline OCB_CO1 & 0.8684 & 0.4412 & 0.7118 & 0.1735 & 0.2396 & ic \\
\hline OCB_CO2 & 0.8347 & 0.3823 & 0.5688 & 0.1369 & 0.2046 & \\
\hline OCB_CO3 & 0.8445 & 0.4214 & 0.7334 & 0.2104 & 0.1566 & \\
\hline OCB_SI1 & 0.3555 & 0.7841 & 0.3827 & 0.3094 & 0.5044 & \\
\hline OCB_SI2 & 0.4026 & 0.8309 & 0.4112 & 0.3269 & 0.3916 & \\
\hline OCB_SI3 & 0.4029 & 0.8397 & 0.4468 & 0.3913 & 0.3889 & 15 \\
\hline OCB_SI4 & 0.4335 & 0.7933 & 0.4119 & 0.5181 & 0.4059 & \\
\hline OCB_IH1 & 0.6140 & 0.3806 & 0.7578 & 0.1468 & 0.1075 & \\
\hline OCB_IH2 & 0.6597 & 0.3592 & 0.7880 & 0.0347 & 0.0845 & \\
\hline OCB_IH3 & 0.6786 & 0.4944 & 0.8878 & 0.2410 & 0.2322 & \\
\hline OCB_IH4 & 0.6939 & 0.4481 & 0.9060 & 0.1912 & 0.2270 & \\
\hline OCB_IH5 & 0.6880 & 0.4125 & 0.8525 & 0.1136 & 0.1816 & \\
\hline OCB_OI1 & 0.1593 & 0.4018 & 0.1922 & 0.8580 & 0.3063 & \\
\hline OCB_OI2 & 0.1630 & 0.4372 & 0.1485 & 0.8758 & 0.3070 & \\
\hline OCB_OI3 & 0.1813 & 0.3308 & 0.1409 & 0.7522 & 0.2570 & \\
\hline EFF_OB1 & 0.2944 & 0.5283 & 0.2917 & 0.2382 & 0.8196 & \\
\hline EFF_OB2 & 0.2669 & 0.5082 & 0.2470 & 0.3549 & 0.8895 & \\
\hline PERC_EFF1 & 0.1199 & 0.4262 & 0.1166 & 0.3694 & 0.8501 & \\
\hline PERC_EFF2 & 0.1951 & 0.4228 & 0.1613 & 0.3000 & 0.8610 & \\
\hline PERC_EFF3 & 0.1665 & 0.3832 & 0.1260 & 0.2238 & 0.8327 & Tabble \\
\hline PERC_EFF4 & 0.1539 & 0.3727 & 0.1352 & 0.2750 & 0.8077 & Cross-loadin \\
\hline \multicolumn{7}{|c|}{ Note: Italics define the variables's loading within the construct itself } \\
\hline
\end{tabular}

\begin{tabular}{|c|c|c|c|c|c|c|c|c|c|}
\hline & AVE & $\begin{array}{l}\text { Composite } \\
\text { reliability }\end{array}$ & $\begin{array}{c}\text { Cronbach's } \\
\alpha\end{array}$ & $\mathrm{CO}$ & $\begin{array}{l}\text { ITG PERC } \\
\text { EFF }\end{array}$ & SI & $\mathrm{IH}$ & OI & \\
\hline $\mathrm{CO}$ & 0.7213 & 0.8859 & 0.8100 & 0.8493 & & & & & \\
\hline ITG_PERC_EFF & 0.7121 & 0.9367 & 0.9192 & 0.2450 & 0.8439 & & & & \\
\hline SI & 0.6599 & 0.8858 & 0.8292 & 0.4890 & 0.5307 & 0.8123 & & & \\
\hline $\mathrm{IH}$ & 0.7062 & 0.9229 & 0.8997 & 0.7863 & 0.2225 & 0.5074 & 0.8404 & & \\
\hline OI & 0.6896 & 0.8690 & 0.7732 & 0.2005 & 0.3503 & 0.4722 & 0.1937 & 0.8304 & Table VI. \\
\hline Reference values & $A V E>0.50$ & $C R>0.70$ & $A C>0.70$ & Fornell & and Larcker's & s (1981) c & criterion & & Convergent validity \\
\hline \multicolumn{9}{|c|}{ Note: Italics define the square root of the AVE of the construct } & and reliability test \\
\hline
\end{tabular}

\begin{tabular}{lcr}
\hline Variable & $R^{2}$ & \\
\hline Conscientiousness (CO) & 0.0590 & Table VII. \\
Spirit of Initiative (SI) & 0.2926 & Pearson's \\
Interpersonal Harmony (IH) & 0.0437 & determination \\
Identification with the Organization (OI) & 0.1276 & coefficients $\left(R^{2}\right)$ \\
\hline
\end{tabular}

created, with randomly drawn observations from the original set of data (with substitution), which allows to test their statistical significance (Hair et al., 2017).

Table VIII shows the effect sizes and the significance of the identified relationships between the variable "ITG Institutionalization" and "OCB variables."

When interpreting the values of $t$-statistics and $p$-value tests, we observe that the values of the relationships between the behavioral dimensions "Spirit of Initiative" and "Identification with the Organization" and "ITG Perceived Effectiveness" are positively significant (Ringle et al., 2014). 
REGE

26,1

16

\section{Results}

Higher OCBs increase people's willingness to make changes in a proactive and receptive way, since a positive and open behavior toward change prevails (Rego et al., 2010). This happens because individuals with high OCB understand that changes are important for the organization. Regarding ITG adoption, research respondents understood the shifts proposed by ITG as positive and necessary to the organization. These changes are usually expressed by the adoption or modification of ITG mechanisms, which ultimately modify the way several IT-related activities are carried out within the IT sector and/or throughout the organization.

Related to the variable "Identification with the Organization" and its positive relationship with the perception of ITG effectiveness, individuals with greater identification with the organization perceive ITG as effective, since they have a predisposition to understand the changes as necessary and beneficial, thus having a more positive view of ITG. On the other hand, individuals with higher initiative understand that they can propose ITG mechanisms, or forms of adoption, and notice that there is room for a joint contribution and definition of the ITG model. Thus, ITG is understood as something that contributes to organize IT activities and the IT sector, rather than an obstacle to the accomplishment of activities.

The behavioral dimensions of Conscientiousness and Interpersonal Harmony did not show significant relationships with ITG Perceived Effectiveness, according to Table VI. We expected that the conscientiousness behavior would have a positive relationship with ITG perceived effectiveness. The fact that employees are aware of their tasks and roles should increase the perception of ITG effectiveness, considering they would understand the organization as a system, and the importance of ITG in the short and long terms. When people show a behavior of avoiding conflict and not upsetting others, which is an attribute of conscientiousness, this should increase the perception of effectiveness due to some mechanisms that contribute to clearer rules, distributive justice and equal treatment regarding how decisions were made (Rego, 1999). For example, ITG works with formal roles and responsibilities that contribute to the arrangement of activities. Accordingly, committees for project analysis (either for execution or financing) stimulate decision making based on objective criteria that apply to all requests, ensuring or encouraging isonomic behaviors. This should reduce resistance because employees would see more equal forms of work in ITG mechanisms, which keep interpersonal harmony by decreasing uncertainties and conflicts in the approval of projects, resources and activities.

However, the expected relationship between Interpersonal Harmony and ITG Perceived Effectiveness was not confirmed; on the contrary, there was a potential negative effect on ITG Perceived Effectiveness. One possible explanation for this fact is that civil servants do not present a high interpersonal harmony behavior, or even do not notice this behavior as a consequence of ITG mechanisms. Another possibility is the presence of self-interest behavior, in which people seek their own satisfaction, most of the time, or have the perception that in the organization each one protects, above all, his/her own interests, trying to get the best for himself/herself (Rego, 2002).

In general terms of the relationship between OCB and ITG perceived effectiveness, other areas end up understanding that the mechanisms are more effective, since the result is better for the whole organization. This occurs especially when employees observe something in a

Table VIII.

Significance test of the relationships between constructs

\begin{tabular}{|c|c|c|c|c|c|c|c|}
\hline & $\begin{array}{c}\text { Original } \\
\text { sample }(0)\end{array}$ & $\begin{array}{l}\text { Sample } \\
\text { mean }(\mathrm{M})\end{array}$ & SD & $\mathrm{SE}$ & $t$-statistics & $p$-value & $\begin{array}{l}\text { Significant } \\
\text { relationships }\end{array}$ \\
\hline CO $\rightarrow I T G$ ITERC_EFF & 0.0499 & 0.0522 & 0.0958 & 0.0958 & 0.5205 & 0.6032 & No \\
\hline SI $\rightarrow I T G$ PERC_EFF & 0.4919 & 0.4915 & 0.0642 & 0.0642 & 7.6661 & 0.0001 & Yes \\
\hline $\mathrm{IH} \rightarrow \mathrm{ITG}$ _PERC_EFF & -0.0935 & -0.0826 & 0.0975 & 0.0975 & 0.959 & 0.3385 & No \\
\hline OI $\rightarrow I T G \_P E R C \_E F F$ & 0.1264 & 0.1284 & 0.0624 & 0.0624 & 2.0253 & 0.0439 & Yes \\
\hline
\end{tabular}


positive way, such as the efforts to help find solutions for other employees' problems. This happens because individuals from a group with high initiative and high identification with the organization work with others outside their team to solve problems and defend the organization from internal or external threats. They have more initiative or proactivity to solve such problems, including those created by the absence of ITG or by the superficial or inadequate understanding of what it represents in conceptual and practical terms.

In addition, individuals with high OCB take the initiative of explaining the reasons and bases for the organizational ITG model to be in a certain way, raising awareness and advising colleagues in the organization. When users or employees have a better understanding due to $\mathrm{OCB}$, they may notice ITG as more effective, even if no change has been made, because they better understand ITG and its purposes. Hence, individuals come to deeply perceive the organization and the changes proposed by ITG.

\section{Final remarks}

This research identified a relationship between individuals' citizenship behavior in an organization and ITG Perceived Effectiveness, in the context of public organizations. It provides practical implications for IT professionals working for the government, and theoretical implications for academics, in the organizational fields of information management and ITG.

The theoretical contribution of the research can be expressed in four ways. The first was the validation of the dimensions proposed by Rego et al. (2010) in the local context. Although there are many similarities between Portugal and Brazil in modus operandi, processes and cultural issues, it was important to validate such dimensions in Brazil.

The second theoretical contribution was the development of a model by adapting already existing scales, with the intention of using it for the analysis of the relationships between individuals' behaviors and the perception of ITG effectiveness. This model can be replicated in future studies in public organizations and private ones, with the necessary changes regarding the different governance objectives and principles between public and private organizations. The adaptation of this scale can be considered as unprecedented, at national and international levels. Previously developed scales focused on economic/financial aspects and indicators to identify effectiveness, and not on people's perceptions, which was developed and validated in this research. Considering that an important part of the efforts related to governance is to create appropriate behaviors for each organization, an effectiveness scale with a focus on behavioral variables brings a significant potential contribution.

The third theoretical contribution was to demonstrate the existence of a positive and significant relationship between the variables Spirit of Initiative and Identification with the Organization, and ITG Perceived Effectiveness. It shows that governance is a complex process of organizational change, through behavioral shifts related to decisions, in this case, decisions about IT resources, which are essential for carrying out public strategies and policies. At first, ITG was seen as the adoption of market models, which was a very simplistic understanding. This paper contributes to the maturity of this area by demonstrating that ITG is a complex process of change in IT decision making and its impacts throughout the organization. Thus, ITG increasingly involves the adoption and use of IT in organizations and not just in the IT department, which is the focus of the IT management area. Finally, the study of ITG in public organizations represents the fourth theoretical contribution, since ITG papers in this context are still scarce (Aasi et al., 2017).

As a practical contribution, managers involved in processes of ITG adoption should consider the impact of the resulting change not only in processes and structures, but also in the behavior of individuals in the organization. Given that IT is political and social (Bekkers and Homburg, 2007), ITG adoption changes the meaning of IT in the organization, as it starts to discuss how IT resources should be used to create competitive advantage (Bartenschlager and Goeken, 2010), or public value in the case of public organizations. Hence, the discussion is 
REGE 26,1

no longer conducted by the IT sector, but it is rather about IT, and this understanding contributes to a better establishment of structures, processes and relationship of IT resources' governance (equipment, applications, information and policies, among others).

Another contribution, which can be both practical and theoretical, is the relevance of the organizational atmosphere and people's relationship with the organization, as a relevant component for ITG effectiveness. Studies on the influence of organizational variables for information protection showed that information security policies are less obeyed and followed when the relationship between chiefs and subordinates is not positive or friendly (Johnston and Warkentin, 2010), or if employees do not perceive fairness in the organizations' actions toward them (Garcia et al., 2018). The same happens with the adoption of ITG mechanisms, especially with the "Spirit of Initiative" and "Identification with the Organization," aspects that were confirmed by this study.

The use of ICT in the public sector can be conceived as a tool to increase trust and promote an inclusive citizen-government relationship, as well as a means for fair ICT policies (Avgerou et al., 2005). This implementation is effective and lasting when part of a process of governance behavioral change. One of the ITG challenges in public organizations is that high-level definitions, such as principles and policies, should be more of a state than of a Government kind; hence, they should not change at each new mandate just to oppose the predecessor. These changes need to be part of a conscientious decision-making process, preceded by discussing and listening to different stakeholders. Thereby, IT actions tend to be more consistent and their implementation more likely to be kept over time, if they are part of an ITG process.

IT managers need to take into account that behavioral changes in individuals, especially those that encourage the Spirit of Initiative and the Identification with the Organization, can contribute in practical terms for the definition of IT policies and ITG mechanisms, and for the establishment of collegiate decision-making structures that are more effective and best protect citizens' interests in IT decisions, rather than the interests of suppliers, political agents or the IT team itself.

Two limitations are important when interpreting research results. The first regards the predictive capacity of the proposed relationship model, which requires a larger number of confirmatory studies. The second refers to the study's context of application and the coverage of results, since data collection was carried out with civil servants of only one Brazilian state. Application of these results to other states, or even to private organizations, needs to consider geographic, cultural or political issues.

As future studies, we suggest the validation of the proposed relationship model in other Brazilian states or in bodies of the Municipal and Federal Public Administration, which would ensure greater reliability and reach of results. The moderating effect of individual attributes (satisfaction, perception of justice, commitment and trust in the leader), personality (conscientiousness, pleasantness, positive and negative affectivity) or individual competencies and differences (experience, qualification, need for independence and indifference to rewards) can affect the relationship between individuals' OCB dimensions and the effectiveness of ITG models. These attributes can have positive or negative effects on individuals' OCB (Podsakoff et al., 2000), and should be explored in future studies. The variables expected to have a positive relationship with ITG effectiveness - Conscientiousness and Interpersonal Harmony - should also be investigated.

\section{References}

Aasi, P., Rusu, L. and Leidner, D. (2017), "IT organizational structure relationship with IT governance performance: case of a public organization", in Rusu, L. and Viscusi, G. (Eds), Information Technology Governance in Public Organizations: Theory and Practice, Springer, Cham, pp. 229-252.

Ali, S. and Green, P. (2007), "IT governance mechanisms in public sector organisations: an Australian context”, Journal of Global Information Management, Vol. 15 No. 4, pp. 41-63. 
Avgerou, C., Ciborra, C., Cordella, A., Kallinikos, J. and Smith, M. (2005), The Role of Information and Communication Technology in Building Trust in Governance: Towards Effectiveness and Results, Inter-American Development Bank, Washington, DC.

Barrett, P. (2001), "Corporate governance - more than good management", Proceedings of the CPA South Australia Annual Congress - Riding the Next Wave, Australian Audit Office, Adelaide, November 16.

Bartenschlager, J. and Goeken, M. (2010), "IT strategy implementation framework - bridging enterprise architecture and IT governance", Proceedings of the Americas Conference on Information Systems, Atlanta, GA, p. 400.

Bekkers, V. and Homburg, V. (2007), "The myths of e-government: looking beyond the assumptions of a new and better government", The Information Society, Vol. 23 No. 5, pp. 373-382.

Bowen, P.L., Cheung, M.Y.D. and Rohde, F.H. (2007), "Enhancing IT governance practices: a model and case study of an organization's efforts", International Journal of Accounting Information Systems, Vol. 8 No. 3, pp. 191-221.

Bresser-Pereira, L.C. (2002), "Incompatibilidade distributiva e desenvolvimento auto-sustentado", in Bielschowsky, R. and Mussi, C. (Eds), Politicas Para a retomada do crescimento: reflexões de economistas brasileiros, IPEA/CEPAL, Brasília, pp. 117-148.

Chin, W.W. (1998), "The partial least squares approach to structural equation modeling", Modern Methods for Business Research, Vol. 295 No. 2, pp. 295-336.

Cunha, M.A.V.C. (2000), "Portal de serviços públicos e de informação ao cidadão: estudos de casos no Brasil (Tese de Doutorado)", Faculdade de Economia, Administração e Contabilidade, Universidade de São Paulo, São Paulo.

Cunha, M.A.V.C. and Miranda, P.R.M. (2013), "O uso de TIC pelos governos: Uma proposta de agenda de pesquisa a partir da produção acadêmica e da prática nacional”, Organizações \& Sociedade, Vol. 20 No. 66, pp. 543-566, doi: 10.1590/S1984-92302013000300010.

Cunha, M.P., Cunha, R.C. and Rego, A. (2009), "Exploring the role of leader - subordinate interactions in the construction of organizational positivity", Leadership, Vol. 5 No. 1, pp. 81-101.

Cunha, M.P., Rego, A. and D'oliveira, T. (2006), "Organizational spiritualities: an ideology-based typology”, Business \& Society, Vol. 45 No. 2, pp. 211-234.

Diniz, E.H., Barbosa, A.F., Junqueira, A.R.B. and Prado, O. (2009), "O governo eletrônico no Brasil: perspectiva histórica a partir de um modelo estruturado de análise", Revista de Administração Pública, Vol. 43 No. 1, pp. 23-48.

Faul, F., Erdfelder, E., Buchner, A. and Lang, A.G. (2009), "Statistical power analyses using G* power 3.1: tests for correlation and regression analyses”, Behavior Research Methods, Vol. 41 No. 4, pp. 1149-1160.

Fornell, C. and Larcker, D.F. (1981), "Structural equation models with unobservable variables and measurement error: algebra and statistics", Journal of Marketing Research, Vol. 18 No. 1, pp. 39-50.

Garcia, P.S., Macadar, M.A. and Luciano, E.M. (2018), "The influence of organizational injustice in the motivation for the practice of cybercrimes", Journal of Information Systems and Technology Management, Vol. 15 No. 1, pp. 1-19, doi: 10.4301/S1807-1775201815002.

Grandori, A. (1997), "Governance structures, coordination mechanisms and cognitive models", Journal of Management \& Governance, Vol. 1 No. 1, pp. 29-47, doi: 10.1023/A:100997762.

Hair, J.F. Jr, Hult, G.T.M., Ringle, C. and Sarstedt, M. (2014), A Primer on Partial Least Squares Structural Equation Modelling (PLS-SEM), Sage Publications, London.

Hair, J.F. Jr, Sarstedt, M., Ringle, C.M. and Gudergan, S.P. (2017), Advanced Issues in Partial Least Squares Structural Equation Modeling, Sage, London.

Heeks, R. (2005), "E-Government as a carrier of context”, Journal of Public Policy, Vol. 25 No. 1, pp. 51-74.

Henseler, J., Ringle, C.M. and Sinkovics, R.R. (2009), "The use of partial least squares path modeling in international marketing", in Sinkovics, R.R. and Ghauri, P.N. (Eds), New Challenges to International Marketing (Advances in International Marketing, Vol. 20), Emerald Group Publishing Limited, pp. 277-319. 
REGE

26,1

Huang, R., Zmud, R.W. and Price, R.L. (2010), "Influencing the effectiveness of IT governance practices through steering committees and communication policies", European Journal of Information Systems, Vol. 19 No. 3, pp. 288-302.

Johnston, B.A.C. and Warkentin, M. (2010), "Fear appeals and information security behaviors: an empirical study", MIS Quarterly, Vol. 34 No. 3, pp. 549-566.

Joia, L.A. (2009), "Governo eletrônico e capital intelectual nas organizações públicas", Revista de Administração Pública, Vol. 43 No. 6, pp. 1379-1405.

Koufteros, X.A. (1999), "Testing a model of pull production: a paradigm for manufacturing research using structural equation modeling", Journal of Operations Management, Vol. 17 No. 4, pp. 467-488.

Laia, M.M., Cunha, M.A.V.C., Nogueira, A.R.R. and Mazzon, J.A. (2011), "Electronic government policies in Brazil: context, ICT management and outcomes", Revista de Administração de Empresas, Vol. 51 No. 1, pp. 43-57.

Luciano, E.M., Wiedenhöft, G.C., Macadar, M.A. and dos Santos, F.P. (2016), "Information technology governance adoption: understanding its expectations through the lens of organizational citizenship", International Journal of IT/Business Alignment and Governance, Vol. 7 No. 2, pp. 22-32.

Lunardi, G.L., Becker, J.L. and Maçada, A.C.G. (2010), "Impacto da adoção de mecanismos de governança de tecnologia de informação (TI) no desempenho da gestão da TI: Uma análise baseada na percepção dos executivos”, Revista de Ciências da Administração, Vol. 12 No. 28, pp. 11-39.

Medeiros, P.H.R. and Guimarães, T.A. (2006), “A institucionalização do governo eletrônico no Brasil”, Revista de Administração de Empresas, Vol. 46 No. 4, pp. 66-78.

Nfuka, E.N. and Rusu, L. (2011), "The effect of critical success factors on IT governance performance", Industrial Management and Data Systems, Vol. 111 No. 9, pp. 1418-1448, doi: 10.1108/ 02635571111182773.

Paillé, P., Bourdeau, L. and Galois, I. (2010), "Support, trust, satisfaction, intent to leave and citizenship at organizational level: a social exchange approach", International Journal of Organizational Analysis, Vol. 18 No. 1, pp. 41-58.

Paine, J.B. and Organ, D.W. (2000), "The cultural matrix of organizational citizenship behavior: some preliminary conceptual and empirical observations", Human Resource Management Review, Vol. 10 No. 1, pp. 45-59.

Peters, B. Guy. (1998), "Managing horizontal government: the politics of coordination", Public Administration, Vol. 76 No. 2, pp. 295-311.

Peterson, R.R. (2004), "Integration strategies and tactics for information technology governance", in Van Grembergen, W., Saull, R. and De Haes, S. (Eds), Strategies for Information Technology Governance, IGI Global, Hershey, PA, pp. 37-80.

Podsakoff, P.M., MacKenzie, S.B., Paine, J.B. and Bachrach, D.G. (2000), "Organizational citizenship behaviors: a critical review of the theoretical and empirical literature and suggestions for future research", Journal of Management, Vol. 26 No. 3, pp. 513-563, doi: 10.1177/014920630002600307.

Prasad, A., Heales, J. and Green, P. (2010), “A capabilities-based approach to obtaining a deeper understanding of information technology governance effectiveness: evidence from IT steering committees", International Journal of Accounting Information Systems, Vol. 11 No. 3, pp. 214-232.

Rego, A. (1999), "Comportamentos de cidadania organizacional - operacionalização de um constructo", Psicologia, Vol. 13 Nos 1-2, pp. 127-148, doi: 10.17575/rpsicol.v13i1/2.563.

Rego, A. (2002), "Climas éticos e comportamentos de cidadania organizacional", Revista de Administração de Empresas, Vol. 42 No. 1, pp. 1-14.

Rego, A., Ribeiro, N. and Cunha, M.P. (2010), "Perceptions of organizational virtuousness and happiness as predictors of organizational citizenship behaviors", Journal of Business Ethics, Vol. 93 No. 2, pp. 215-235, doi: 10.1007/s10551-009-0197-7. 
Ringle, C.M., Silva, D. and Bido, D. (2014), "Modelagem de equações estruturais com utilização do SmartPLS”, Revista Brasileira de Marketing, Vol. 13 No. 2, pp. 56-73, doi: 10.5585/remark. v13i2.2717.

Rocheleau, B. and Wu, L. (2002), "Public versus private information systems: do they differ in important ways?”, American Review of Public Administration, Vol. 32 No. 4, pp. 379-397.

Rodrigues, J.G.L. and Souza, J.N. (2012), "Diretrizes para implantação da governança de tecnologia da informação no setor público brasileiro à luz da Teoria institucional”, RSP-Revista do Serviço Público, Vol. 63 No. 4, pp. 475-497.

Sambamurthy, V. and Zmud, R.W. (1999), "Arrangements for information technology governance: a theory of multiple contingencies”, MIS Quarterly, Vol. 23 No. 2, pp. 261-290, doi: 10.2307/249754.

Smith, C.A., Organ, D.W. and Near, J.P. (1983), "Organizational citizenship behavior: its nature and antecedents", Journal of Applied Psychology, Vol. 68 No. 4, pp. 653-663.

Van Grembergen, W., De Haes, S. and Guldentops, E. (2004), "Structures, processes and relational mechanisms for IT governance", in Van Grembergen, W., Saull, R. and De Haes, S. (Eds), Strategies for Information Technology Governance, IGI Global, Hershey, PA, pp. 1-36.

Weill, P. and Ross, J.W. (2004), IT Governance: How Top Performers Manage IT Decision Rights for Superior Results, Harvard Business School Press, Boston, MA.

Wiedenhoft, G. and Klein, R.H. (2013), "Identificação de mecanismos para atender os objetivos e princípios de Governança de TI na visão de profissionais da área”, Revista Eletrônica de Sistemas de Informação, Vol. 12 No. 2, pp. 1-28, doi: 10.5329/RESI.2013.1202001.

Wu, S.P.J., Straub, D.W. and Liang, T.P. (2015), "How information technology governance mechanisms and strategic alignment influence organizational performance: insights from a matched survey of business and IT managers", MIS Quarterly, Vol. 39 No. 2, pp. 497-518.

\section{Further reading}

Katz, D. and Kahn, R.L. (1978), The Social Psychology of Organizations, Wiley, New York, NY.

\section{Corresponding author}

Guilherme Costa Wiedenhöft can be contacted at: guilherme.wiedenhoft@pucrs.br

Associate Editor: Adriana Marotti de Mello

For instructions on how to order reprints of this article, please visit our website: 